\title{
Analysis of Post-Stroke Anxiety (PSA) Factors during the COVID- 19 Pandemic in Indonesia
}

\author{
Nisfil Mufidah \\ STIKes Ngudia Husada Madura, East Java, Indonesia \\ Corresponding author email: nisfil_nhm@yahoo.com \\ M. Suhron \\ STIKes Ngudia Husada Madura, East Java, Indonesia \\ Rahmad Wahyudi \\ STIKes Ngudia Husada Madura, East Java, Indonesia
}

\begin{abstract}
This study aims to determine the incidence of PSA and the factors that influence it. The study was conducted on 78 patients with neurologic stroke at ANNA Medika Madura Hospital from May to July 2021 and aged over 40 years using simple random sampling. Measuring tools using Hamilton Anxiety Rating Scale, vascular disorders, stroke disorders, and Neurophysiological disorders. Analysis using the Structural Equation Modeling with the software Partial Least Square. Based on the results of statistical tests, it was found that demographic factors (Tstatistics 1.756), vascular disorders factor (T-statistics 2.873), stroke disturbance factor (T-statistics 2.164), and neurophysiological disorders factor (T-statistic 3.070). The factor that had the greatest influence on PSA was the neurophysiological factor, with the most influencing subfactor being the cognitive function of stroke patients indicated with MMSE results. Stroke patients with decreased cognitive function will affect the effectiveness of the rehabilitation program. This will lead to an increase in their anxiety with the subsequent effect being a decrease in the quality of life in stroke patients. So rated important for the power of Health assess cognitive function is to reduce PSA.
\end{abstract}

Keywords---COVID-19, neurologic stroke, patient stroke, post-stroke anxiety, risk factors

\section{Introduction}

Stroke is a leading cause of death both globally and a major cause of disability with increasing incidence in developing countries (Campbell et al., 2019). Stroke is divided into two types, namely ischemic stroke and hemorrhagic stroke. Ischemic stroke occurs when a blood vessel that supplies blood to the brain becomes blocked. This type of stroke is the most common (almost $90 \%$ of strokes are ischemic strokes). While hemorrhagic strokes are caused by leaky or ruptured blood vessels in the brain or around the brain, thereby stopping the blood supply to the targeted brain tissue (Kanggeraldo et al., 2018). These nerve disorders cause several complaints including facial paralysis or limbs, speech is not fluent, speech is not clear (pelo), changes in consciousness, and visual disturbances. Stroke has a high morbidity rate that causes disability or weakness on one side of the body, confusion, difficulty walking, loss of balance, and headaches (Dalimunthe et al., 2019). This can have a long-term impact, namely poststroke affective disorder called PSA (Post Stroke Anxiety) which often occurs during the rehabilitation period (Ahmed et al., 2020).

In December 2019, in Wuhan, Hubei Province, China, there were reports of an outbreak of pneumonia of unknown origin. This disease was later called COVID-19 (Corona Virus Disease 2019) because the virus that caused the incident was the coronavirus (SARS-CoV-2). Thousands of deaths caused by the disease led the world health organization to declare a pandemic on March 12, 2020. In mid-2021, the number of cases caused by this disease again experienced an increase in the number of patients, so the government declared the $2^{\text {nd }}$ wave of COVID-19 
pandemic (Tsai et al., 2021). One of the comorbid diseases that are at risk of increased mortality in COVID-19 cases is stroke. A history of stroke increases the risk of death from COVID-19 by 3 times (y Galán, 2020).

Based on data from the Ministry of Health of the Republic of Indonesia in 2014, every year around 500,000 Indonesians suffer a stroke, about $2.5 \%$ of them die, and the rest are severely and lightly disabled. Riskesdas 2018 data shows the prevalence of stroke increased by $7 \%$ in 2013 and 2018 to $10.9 \%$ (Riskesdas, 2018). The results of a preliminary study on 10 stroke patients at ANNA Medika Madura Hospital found 2 respondents with mild anxiety, 3 respondents with moderate anxiety, and 5 respondents with severe anxiety. The most dominant symptoms felt by them were sleep disturbances and feelings of anxiety about their thoughts (Purnama et al., 2020; Beauchamp et al., 2020).

Several factors that influence the anxiety of post-stroke patients include decreased physiological function and sudden stroke attacks, negative perceptions, traumatic experiences, and family support. The higher the anxiety in stroke patients, it will have an impact on decreasing the quality of life and adding to the feeling of excessive anxiety. Family support is assistance provided by other family members to provide physical and psychological comfort for people who are in anxious situations. With family support, it will help patients in dealing with existing health problems, good family support greatly affects the patient's spirit (Hamjah et al., 2019).

Based on the above background, this study has two specific objectives, namely to analyze the prevalence of PSA (Post Stroke Anxiety) and to determine the risk factors associated with PSA. The risk factors include demographic factors (age, gender, and education level); vascular disturbance factors (diabetes mellitus, hypertension, smoking, and alcohol); parese location factors (right, left, and bilateral); and neurophysiological test factors, including Mental State/ MMSE (Mini-Mental State Examination), Stroke Severity/ NIHSS (National Institute Health Stroke Scale), and Neurologic Disability/MRS (Modified Ranking Scale) (Ojagbemi et al., 2020; Ping \& Songhai, 2008).

\section{Method}

The study was conducted on 78 patients with neurologic stroke at ANNA Medika Madura Hospital who met the criteria. Inclusion criteria included respondents being active control patients from May to July 2021 and aged over 40 years. Meanwhile, the exclusion criteria included respondents who were previously diagnosed with mental disorders, severe aphasia, and confusion. Sampling was done by using simple random sampling. Data collection begins with informed consent and continues with filling out a questionnaire (Najman et al., 2020; Hussin et al., 2021). Measuring tools using a questionnaire, including PSA data using HARS (Hamilton Anxiety Rating Scale), demographic data, data on vascular disorders, stroke disorders, and neurophysiological disorders. Neurophysiological disorders include MMSE (Mini-Mental State Examination), NIHSS (National Institute Health Stroke Scale), and MRS (Modified Ranking Scale). After that, the data will be tested statistically using the PLS SAM test.

\section{Result}

The test was carried out by observing the respondent's data that had been collected, following the demographic data of the research sample.

Table 1

Characteristics demographics

\begin{tabular}{lll}
\hline Characteristics Demographics N (78) & $\mathrm{N}=\%$ & Mean \pm SD \\
\hline Gender & & \\
Male & $41(47)$ & $1.53 \pm 0.50$ \\
Female & $37(53)$ & \\
Age & & \\
Middle & $36(46)$ & $37.8 \pm 0.57$ \\
Elderly & $39(50)$ & \\
Elderly & $36(4)$ & $1.00 \pm 0.00$ \\
Marital status & & \\
Married & $78(100)$ & $4.58 \pm 1.5$ \\
Employment & & \\
Full time / part time & $64(82)$ & \\
Unemployed / retired & $14(18)$ & \\
\hline
\end{tabular}




\begin{tabular}{lll}
\hline Education & $38(48)$ & $3.04 \pm 1.57$ \\
$\begin{array}{l}\text { Primary School } \\
\text { Junior high schools }\end{array}$ & $5(6)$ & \\
$\begin{array}{l}\text { Senior high schools/bachelor } \\
\text { Diabetes mellitus disease }\end{array}$ & $25(46)$ & \\
No & $56(72)$ & $1.28 \pm 1.9$ \\
Yes & $22(28)$ & \\
Hypertension disease & & $1.65 \pm 0.47$ \\
No & $27(34)$ & \\
Yes & $51(66)$ & $1.17 \pm 3.75$ \\
Smoking & $65(83)$ & \\
No & $13(17)$ & $1: 00 \pm 0: 00$ \\
Yes & $78(100)$ & \\
Alcohol consumption & & $1.94 \pm 0: 58$ \\
No. & $16(21)$ & \\
parese & $51(65)$ & \\
No & $11(14)$ & $3: 44 \pm 0.84$ \\
Lateral & & \\
Bilateral & $5(6)$ & \\
Stroke period & $3(4)$ & \\
$\leq 3$ month & $23(29)$ & \\
5 month & $47(60)$ & \\
$\geq 5-1$ years & & \\
$>1$ year & & \\
\hline
\end{tabular}

$\mathrm{N}=$ Number of

$\mathrm{SD}=$ Standard deviation 


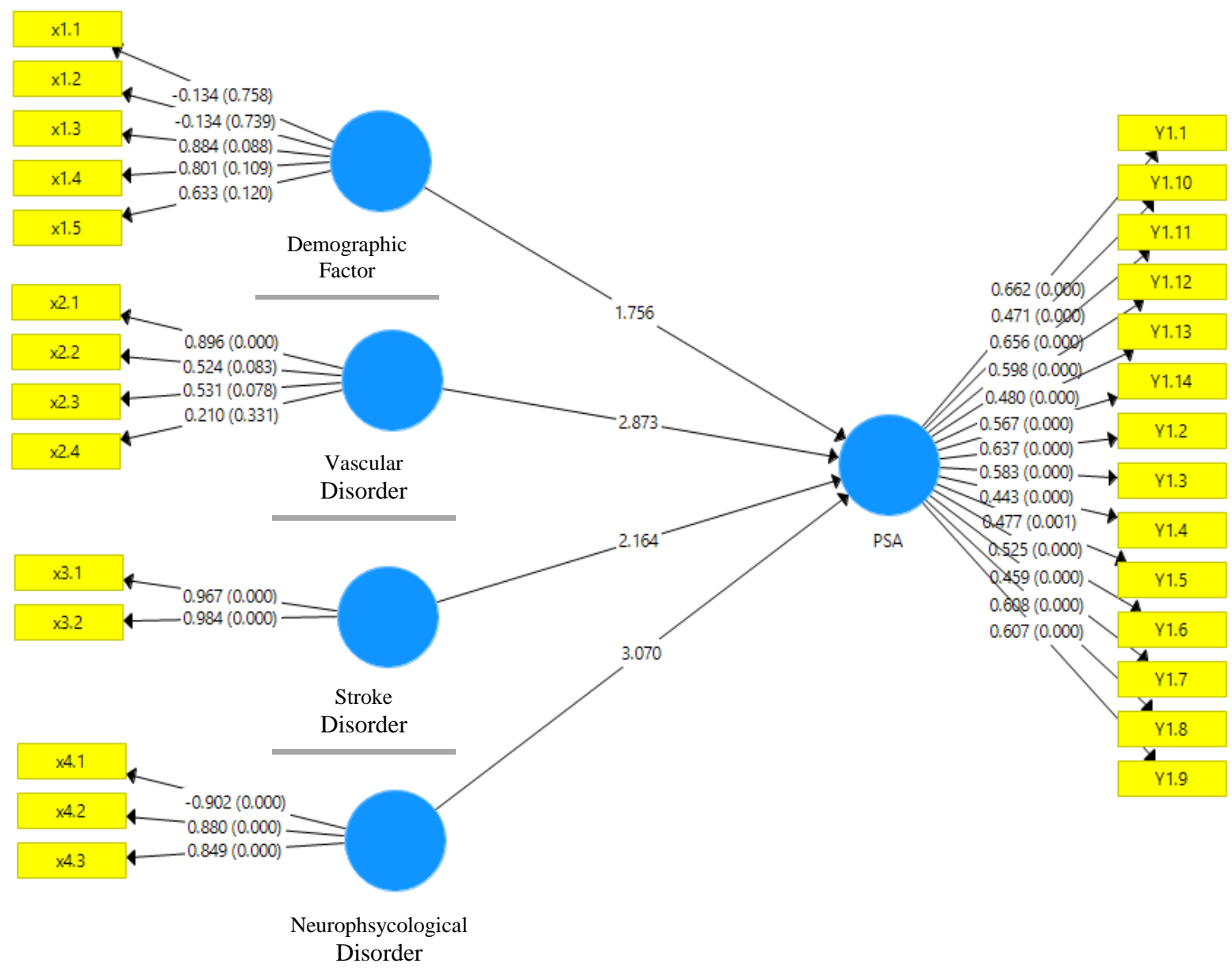

Figure 1. Result of structural model significance test (inner model) based on T statistic

Table 2

Causality relationship

\begin{tabular}{|c|c|c|c|}
\hline No & Relationship & T-statistic & Effect \\
\hline 1 & $\begin{array}{l}\text { (X1) Demographic Factor } \longrightarrow \\
\text { (Y1) PSA }\end{array}$ & 1,756 & Not Significant \\
\hline 2 & $\begin{array}{l}\text { (X2) Vascular Disorder } \longrightarrow \\
\text { (Y1) PSA }\end{array}$ & 2,873 & Significant \\
\hline 3 & $\begin{array}{l}\text { (Y1) Stroke Disorder } \longrightarrow \\
\text { (Y2) PSA }\end{array}$ & 2,164 & Significant \\
\hline 4 & $\begin{array}{l}\text { (Y1 ) Neurophsycological Disorders } \\
\text { (Y2) PSA }\end{array}$ & 3,070 & Significant \\
\hline
\end{tabular}

source: premier

Based on the results of the structural model significance test (inner model) based on T statistics, 3 factors influenced PSA, namely Vascular Disorders with a statistical T value (2.873), Stroke Disorders with a statistical T value (2.164), and Neuropsychological Disorders with a statistical T value $(3,070)$, while there is only one factor that has no effect on this model, namely demographic factors with a T statistic $(1,756)$. The biggest factor in influencing PSA is the neurophysiological factor (Vogrig et al., 2021; Crippa et al., 2020).

Table 1 shows the data of the four factors studied that can cause PSA incidence during the COVID-19 pandemic, in order from the most significant, neurophysiological disorders $(\mathrm{p}=3.070)$, vascular disorders $(\mathrm{p}=2.873)$. $)$, and 
stroke disorders $(\mathrm{p}=2.164)$, while the not significant effect causing PSA was demographic factors $(\mathrm{p}=1.756)$. The influence of demographic factors in this study was found to be insignificant in causing the incidence of PSA. The incidence of PSA during the COVID-19 pandemic in China was reported to be around 13.3\% compared to the time before the pandemic of around $1.2-27 \%$. The incidence of PSA is higher in female patients than male patients because female patients are more susceptible to psychological stress, depressive symptoms, and anxiety (Yao et al., 2021). However, the results of this study found that the number of stroke patients was more male than female, but from this gender, data obtained results that did not significantly affect the incidence of PSA. Marital status (divorced or widowed) was not found as an independent risk factor for PSA. Decreasing friendship relations can reduce social support so that the incidence of PSA can increase (Yao et al., 2021).

The effects of vascular disorders that can cause PSA studied include diabetes mellitus, hypertension, smoking, and alcohol consumption. The most significant data showed that PSA was caused by diabetes mellitus ( $\mathrm{p}=0.896)$. This is due to the impact of decreased vascular function and the interaction between vascular load and neurodegenerative lesions, thereby reducing pancreatic function (Wang et al., 2018). The influence of stroke disorders that can cause PSA studied includes the location of the paresis and the duration of stroke. The most significant data obtained was due to the length of stroke experienced by the patient $(\mathrm{p}=0.984)$. PSA is common during the first post-stroke year with a probability of 1 in 3 stroke patients (Rafsten et al., 2018). This is because the longer the duration of a person having a stroke, the vascular function and vascular load decreases, causing neurodegenerative and causing PSA (Wang et al., 2018). The influence of physiological disorders studied that can cause PSA includes MMSE, NIHSS, and MRS, with the most significant data being the MMSE (Mini-Mental State Examination) ( $\mathrm{p}=0.902)$. It is said that cognitive function and anxiety were assessed using the MMSE. There is a high correlation between the occurrence of anxiety in the sub-acute stroke phase and 2 months after stroke as evaluated by the MMSE (Quattropani et al., 2018). Anxiety symptoms were analyzed using HAMA (Hamilton Anxiety Rating Scale). Patients are said to have PSA when the HAMA score is $>7$ points (Wang et al., 2018). This is in line with research conducted by (Agus full moon, 2020) According to the results of research that stress with cognitive function has a relationship with the cognitive function of $2.6 \%$, this is because stress with specific cognitive functions is closely related, because in situations Stress is very risky for cognitive decline, especially for elderly people. Experiencing a post-stroke state creates stressful conditions that tend to increase the risk of cognitive decline. Anxiety is a common symptom in patients after a stroke (Siow et al., 2021; Qureshi et al., 2020). Systematic studies over the last 10 years have reported that approximately $20 \%$ of patients with stroke experience some degree of anxiety. Patients with PSA are worried about stroke recurrence, decreased ability to work, and the risk of falling so that it can reduce their quality of life (Rafsten et al., 2018).

\section{Conclusion}

Based on the results of the research conducted, it can be concluded that the biggest factor that can cause patients to experience PSA (Post Stroke Anxiety) during the COVID-19 pandemic is neurophysiological factors. While the neurophysiological subfactor that has the most influence is the cognitive function of stroke patients.

\section{Acknowledgments}

We would like to appreciate those who are participating in this study. The manuscript was written in fulfillment of the requirement to obtain Output of "Hibah Program Kompetisi Kampus Merdeka, Kementerian Pendidikan, Kebudayaan, Riset, dan Teknologi, Indonesia and STIKES Ngudia Husada Madura" The author declares that three is no conflict of interest regarding the publication of this article

\section{References}

Ahmed, Z. M., Khalil, M. F., Kohail, A. M., Eldesouky, I. F., Elkady, A., \& Shuaib, A. (2020). The Prevalence and Predictors of Post-Stroke Depression and Anxiety During COVID-19 Pandemic. Journal of Stroke and Cerebrovascular Diseases, 29(12), 105315. https://doi.org/10.1016/j.jstrokecerebrovasdis.2020.105315

Beauchamp, J. E. S., Montiel, T. C., Cai, C., Tallavajhula, S., Hinojosa, E., Okpala, M. N., ... \& Sharrief, A. Z. (2020). A retrospective study to identify novel factors associated with post-stroke anxiety. Journal of Stroke and Cerebrovascular Diseases, 29(2), 104582. https://doi.org/10.1016/j.jstrokecerebrovasdis.2019.104582

Campbell, B. C., De Silva, D. A., Macleod, M. R., Coutts, S. B., Schwamm, L. H., Davis, S. M., \& Donnan, G. A. (2019). Ischaemic stroke. Nature Reviews Disease Primers, 5(1), 1-22. 
Crippa, S., Kägi, G., Graf, L., Sauteur, P. M., \& Kohler, P. (2020). Stroke in a young adult with mild COVID-19 suggesting endotheliitis. New Microbes and New Infections, 38, 100781. https://doi.org/10.1016/j.nmni.2020.100781

Dalimunthe, B., Setiawan, S., Siregar, C. T., Tanjung, D., \& Harahap, I. A. (2019). Perception Of Family As Caregiver About The Implementation Of Oral Care In Caring For Stroke Patients In Medan City: A Preliminary Action Research. International Journal of Nursing and Health Services (IJNHS), 2(3), 150-157.

Hamjah, A., Praptiwi, A., \& Sari, E. A. (2019). Kecemasan Kematian pada Pasien Stroke. Jurnal Keperawatan'Aisyiyah, 6(1), 27-36.

Hussin, D. A., Samah, M. A. A., Suhaimi, A. A., \& Kamarudin, M. K. A. (2021). A study on knowledge, attitude and practice of COVID-19 pandemic among the residents. International Journal of Health Sciences, 5(2), 177188. https://doi.org/10.29332/ijhs.v5n2.1378

Kanggeraldo, J., Sari, R. P., \& Zul, M. I. (2018). Sistem Pakar Untuk Mendiagnosis Penyakit Stroke Hemoragik dan Iskemik Menggunakan Metode Dempster Shafer. Jurnal RESTI (Rekayasa Sistem dan Teknologi Informasi), 2(2), 498-505.

Najman, N., Kistan, K., \& Novianti, I. (2020). The relationship on health education against anxiety concerning COVID-19 transmission. International Journal of Health Sciences, 4(3), 69-74. https://doi.org/10.29332/ijhs.v4n3.464

Ojagbemi, A., Akinyemi, J., Owolabi, M., Akinyemi, R., Arulogun, O., Gebregziabher, M., ... \& Ovbiagele, B. (2020). Predictors and prognoses of new onset post-stroke anxiety at one year in black Africans. Journal of Stroke and Cerebrovascular Diseases, 29(9), 105082. https://doi.org/10.1016/j.jstrokecerebrovasdis.2020.105082

Ping, W., \& Songhai, L. (2008). Clinical observation on post-stroke anxiety neurosis treated by acupuncture. Journal of Traditional Chinese Medicine, 28(3), 186-188. https://doi.org/10.1016/S0254-6272(08)60043-6

Purnama, A., Afrina, R., \& Shifa, N. A. (2020). Stress and Relationship with Cognitive Disorders of Post-Stroke Patients. STRADA Jurnal Ilmiah Kesehatan, 9(1), 1-5.

Quattropani, M. C., Geraci, A., Lenzo, V., Delle Chiaie, R., \& Filastro, A. (2018). Post stroke anxiety and depression: relationships to cognitive rehabilitation outcome. Clin. Neuropsychy. J. Treat Eval, 15, 12-18.

Qureshi, A. I., Abd-Allah, F., Al-Senani, F., Aytac, E., Borhani-Haghighi, A., Ciccone, A., ... \& Wang, Y. (2020). Management of acute ischemic stroke in patients with COVID-19 infection: insights from an international panel. The American Journal of Emergency Medicine, 38(7), 1548-e5. https://doi.org/10.1016/j.ajem.2020.05.018

Rafsten, L., Danielsson, A., \& Sunnerhagen, K. S. (2018). Anxiety after stroke: a systematic review and metaanalysis. Journal of Rehabilitation Medicine, 50(9), 769-778.

Siow, I., Lee, K. S., Zhang, J. J., Saffari, S. E., Ng, A., \& Young, B. (2021). Stroke as a neurological complication of COVID-19: a systematic review and meta-analysis of incidence, outcomes and predictors. Journal of Stroke and Cerebrovascular Diseases, 30(3), 105549. https://doi.org/10.1016/j.jstrokecerebrovasdis.2020.105549

Tsai, S. C., Lu, C. C., Bau, D. T., Chiu, Y. J., Yen, Y. T., Hsu, Y. M., ... \& Yang, J. S. (2021). Approaches towards fighting the COVID-19 pandemic. International journal of molecular medicine.

Vogrig, A., Gigli, G. L., Bnà, C., \& Morassi, M. (2021). Stroke in patients with COVID-19: Clinical and neuroimaging characteristics. Neuroscience letters, 743, 135564. https://doi.org/10.1016/j.neulet.2020.135564

Wang, Q., Zhao, K., Cai, Y., Tu, X., Liu, Y., \& He, J. (2018). Prediabetes is associated with post-stroke cognitive impairment in ischaemic stroke patients. Brain research, 1687, $137-143$. https://doi.org/10.1016/j.brainres.2017.12.034

y Galán, J. T. G. (2020). Stroke as a complication and prognostic factor of COVID-19. Neurología (English Edition), 35(5), 318-322. https://doi.org/10.1016/j.nrleng.2020.04.013

Yao, M., Li, H., Luo, Y., Li, L., \& Yu, J. (2021). High Prevalence of Post-stroke Anxiety in Elderly Patients Following COVID-19 Outbreak. Frontiers in psychiatry, 12. 